\title{
Preference of consumers regarding purchase of western dresses
}

\author{
Pushpinder Kaur and Vandana Gandotra
}

Received: 07.02.2020; Revised: 12.03.2020; Accepted: 27.04.2020

See end of the paper for authors' affiliations

\section{Pushpinder Kaur}

Department of Apparel and

Textile Science, College of

Home Science, Punjab

Agricultural University,

Ludhiana (Punjab) India

Email : pushusekhon94@gmail.

com
ABSTRACT : The present study was undertaken to study the preferences of consumer regarding purchase of western dresses. An interview schedule was framed for collecting the preference off respondents and sources of information, factors and various constructional features. The results of the collected data revealed that the most important source of gathering information in dresses was internet followed by television. Most of the respondents preferred to purchase dresses from boutiques and retail shops. The most important factor considered by respondents was price and comfort.

KEY WORDS: Western dresses, Saree, Ghagra choli, Salwar kameez, Boutiques

-HOW TO CITE THIS PAPER : Kaur, Pushpinder and Gandotra, Vandana (2020). Preference of consumers regarding purchase of western dresses. Asian J. Home Sci., 15 (1) : 63-65, DOI: 10.15740/HAS/AJHS/ 15.1/63-65. Copyright@ 2020: Hind Agri-Horticultural Society. 